\title{
Finnish records on the genus Inocybe. The new species Inocybe saliceticola
}

\author{
JUKKA VAURAS and KATRI KOKKONEN
}

VAURAS, J. \& KOKKONEN, K. 2009: Finnish records on the genus Inocybe. The new species Inocybe saliceticola. - Karstenia 48: 57-67. Helsinki. ISSN 0453-3402.

\begin{abstract}
Inocybe saliceticola, a new species of section Marginatae, is described from Finland. It is characterized by ochraceous pileus, bulbous stipe base and weakly nodulose spores. It grows with Salix in moist habitats. The holotypes of I. alnea, I. dunensis, I. obtusiuscula, I. ochracea and I. straminipes are treated. I. straminipes is reduced to a synonym of $I$. salicis. The synonymy of I. ochracea with I. alnea is supported by DNA analysis. The microscopical drawings of the type of I. obtusiuscula are given for the first time.
\end{abstract}

Key words: Agaricales, Basidiomycetes, Finland, Inocybe, Salix, taxonomy

Jukka Vauras, Biological Collections of Abo Akademi University, Herbarium, FI-20014 University of Turku, Finland

Katri Kokkonen, Mahalanniementie 150, FI-75700 Valtimo, Finland; Herbarium, FI-20014 University of Turku, Finland

\section{Introduction}

The genus Inocybe is one of the largest genera of Agaricales in the Nordic countries. In the book Funga Nordica there are 154 species of Inocybe in the key (Jacobsson 2008). Several species of Inocybe are known to grow associated with Salix. From moist Salix thickets in Finland, the authors have collected a nodulose-spored species of Inocybe, which does not fit to any known taxon of Inocybe. We describe it here as a new species, Inocybe saliceticola. For comparison, we have studied the type specimens of I. alnea Stangl, I. dunensis P.D. Orton, I. obtusiuscula Kühner, I. ochracea Stangl, I. salicis Kühner and I. straminipes Romagn. In addition to morphology, ITS (Internal Transcribed Spacer) regions within ribosomal DNA were studied from some specimens. The variation in ITS is commonly regarded useful to separate agaric species. The differences between I. saliceticola and macroscopically fairly similar species are pointed out to help identifications.

\section{Material and methods}

The description of Inocybe saliceticola is based on ca. 20 specimens from Finland, most of which collected by the authors. Untypical specimens by spores (marked with * in chapter Specimens examined), and one with nearly glabrous stipe $(* *)$, were excluded from the description. The acronyms of the herbaria follow those used by Holmgren et al. (1990).

Macroscopical characteristics were noted and cross sections drawn from fresh fruit bodies. Given colour codes refer to Cailleux (1981) or Küppers (1999). Vegetation, especially trees and bushes, were observed at the growth sites. At four sites in the province Pohjois-Karjala (communes of Valtimo and Nurmes), samples were taken from soil surface in order to analyse $\mathrm{pH}$ and quantities of nutrients. The samples were analysed by Viljavuuspalvelu Ltd.

Microscopical characteristics were measured and drawn from dried material mounted in $10 \% \mathrm{NH}_{4} \mathrm{OH}$ solution at $1000 \times$ magnification. Twenty mature spores were measured from each of 10 collections and from each of two fruit bodies of I. saliceticola holotype (totalled 240 spores). The number of 89 pleurocystidia were measured from 10 collections of $I$. saliceticola. Twenty spores were measured from each other Inocybe type studied. The spores were measured including the nodules, the cystidia lengths excluding the crystals, and the basidia lengths ex- 
cluding the sterigmata. Given length $\times$ width of spores and pleurocystidia is a $95 \%$ confidence interval with underlined mean in center and range in parentheses. The $\mathrm{Q}$ value means the ratio of spore length to spore width (calculated for each spore).

The ITS sequence including 5.8S of rDNA was analysed from the holotype of I. saliceticola, another collection from the type site (Kokkonen \& Vauras 23082F) and from four untypical collections to see, whether the untypical ones were within the species limits. Mika Toivonen (University of Helsinki) analysed two of these collections. Furthermore, ITS was analysed from the types of I. obtusiuscula, I. alnea, I. ochracea and I. hirculus for comparison. We also wanted to assure ourselves that I. ochracea is conspecific with I. alnea. The DNA was extracted from $0.2-2.3 \mathrm{mg}$ of dried lamella by NucleoSpin Plant or NucleoSpin Tissue XS kit (Macherey-Nagel). The PCR primers were ITS1-F, ITS4-B, ITS2 or ITS3 (White et al. 1990, Gardes \& Bruns 1993). The PCR was run by GeneAmp PCR system 9700 (PE Applied Biosystems) with PuRe Taq Ready-To-Go PCR beads (Amersham Biosciences). There were $30-36$ cycles consisting of $1 \mathrm{~min}$ at $94^{\circ} \mathrm{C}, 1 \mathrm{~min}$ at $55^{\circ} \mathrm{C}$ and $1 \mathrm{~min}$ at $72^{\circ} \mathrm{C}$. The PCR products were purified with GFX PCR DNA and Gel Band Purification kit (Amersham Biosciences) and sent to Macrogen Inc. for sequencing. The primers ITS1, ITS4, ITS2 or ITS3 were used for sequencing. The sequences were edited by Seqman (DNAStar), aligned by ClustalW (www.ebi.ac.uk/clustalw/) and compared visually. Ambiguous bases were excluded from the comparisons.

Inocybe saliceticola Vauras \& Kokkonen, spec. nova - Figs. $1-5$

MycoBank no.: MB 513002

Pileo 0.7-4 cm lato, potissimum flavo-brunneo. Lamellis usque ad $7.5 \mathrm{~mm}$ latis, mediocriter ventricosis. Stipite 0.7-6.2 cm longo, 1.5-6.5 mm crasso, pallido, omnino albo-pruinoso, basi frequenter marginato-bulboso. Sporis (7.2-)7.9$10.9(-11.6) \times(5.1-) 5.7-7.1(-7.9) \mu m$, angulatonodulosis. Pleurocystidiis 41-89 × 12-23 $\mu$, nonnihil ventricosis. Caulocystidia per totam longitudinem stipitis praesentia. Cum Salicibus.

Holotype: Finland, Pohjois-Karjala, Nurmes, Salmi, E shore of lake Pahakala, moist shore forest, near Salix phylicifolia, S. myrsinifolia, S. pentandra, S. cinerea, Betula, Alnus incana, Equisetum arvense, Lysimachia thyrsiflora, Filipendula ulmaria, Ranunculus repens, Calliergon cordifolium and Inocybe acuta, Grid $27^{\circ} \mathrm{E}$ : 70392:6018, alt. ca. 103 m, 31.VII.2003 K. Kokkonen \& J. Vauras 19738F, GenBank no.
FJ755796 (TUR-A; isotype in MICH).

Etymology: saliceticola (Latin), refers to the habitat of the species amongst bushes of Salix.

Pileus 7-40 $\mathrm{mm}$ in diameter, 4-11 $\mathrm{mm}$ high, conical to paraboloid when young, then conico-convex to applanate, prominently umbonate but sometimes only indistinctly umbonate, centre smooth, outwards radially fibrillose, rarely breaking up, no velipellis observed; yellow-brown (S30Y70M40, 67N) to pale brown (S30Y50-60M30), sometimes rather strongly contrasting with the centre, which is red-brown (S30Y60M50, 49P), dark red-brown (S60Y60M50-60) or grey-brown (S40Y70M50), outmost margin often the palest.

Lamellae up to $5 \mathrm{~mm}$, rarely to $7.5 \mathrm{~mm}$ broad, moderately crowded, somewhat ventricose, narrowly adnate, when young pale grey (S20Y30M10), pale grey-brown (S20Y40M10-20, 91K), later grey-brown (S30Y50M20, Y60M50C30), edge minutely fimbriate, concolorous or paler.

Stipe $0.7-6.2 \mathrm{~cm}$ long, $1.5-6.5 \mathrm{~mm}$ wide, equal or slightly widening towards the base, with large, often emarginate, up to $11 \mathrm{~mm}$ wide bulb, solid, whitish, pale yellow-brown (ca. S00Y40M10), pale brown, pale red-brown (S10Y50M20), rarely grey-brown (ca. S20Y50M30), base white; white-pruinose all over, longitudinally striate.

Cortina not observed.

Context in pileus whitish to pale brownishgrey to pale yellowish, in stipe concolorous or slightly paler compared with the stipe surface, longitudinally striate. Smell and taste weak, fungoid.

Spores (7.2-)7.9-9.2-10.9(-11.6) $\times(5.1-$ )5.7-6.3-7.1(-7.9) $\mu \mathrm{m}$, total range of mean values $8.6-10.4 \times 5.9-6.5 \mu \mathrm{m}, \mathrm{Q}=(1.15-) 1.25-$ $\underline{1.46}-1.7(-1.8)$, total range of mean $\mathrm{Q}$ values $=$ 1.31-1.59; subangular, with few, obtuse nodules, apex at times elongated. Basidia 25-40 × 9-14 $\mu \mathrm{m}$, clavate, 4-spored.

Pleurocystidia (41-)50-67-84(-89) $\times(12-$ )13-17-23 $\mu \mathrm{m}$, narrowly to broadly ventricose with long or short neck, rarely clavate, apex crystalliferous, at times bent, base tapered or with pedicel, wall up to $4.5 \mu \mathrm{m}$ thick, yellowish. Cheilocystidia similar to pleurocystidia, but generally shorter and more ventricose, scattered 

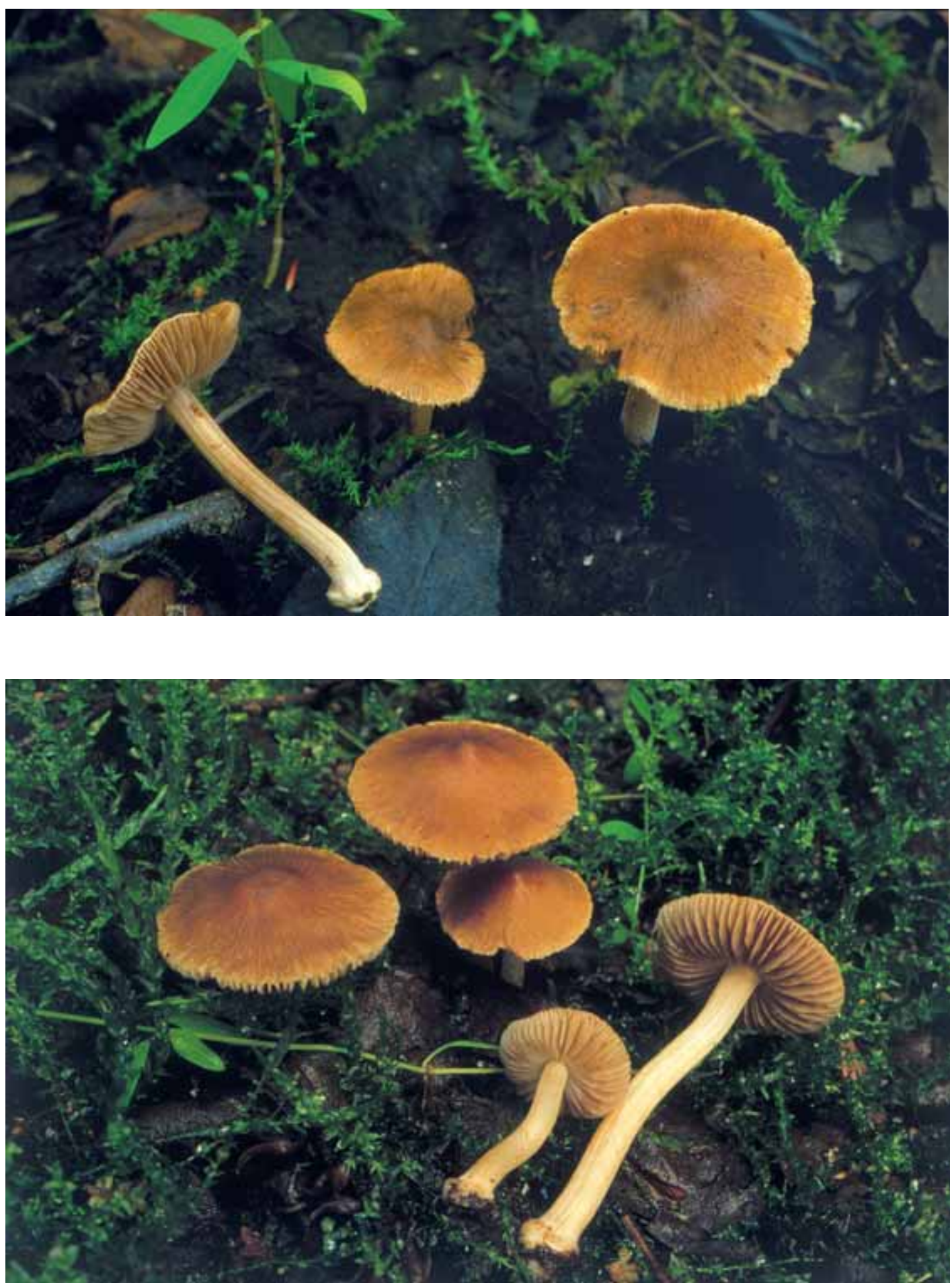

Figs. 1-2. Fruit bodies of Inocybe saliceticola in situ in type locality. - 1: Holotype. - 2: Collection Kokkonen \& Vauras $23082 F$. 


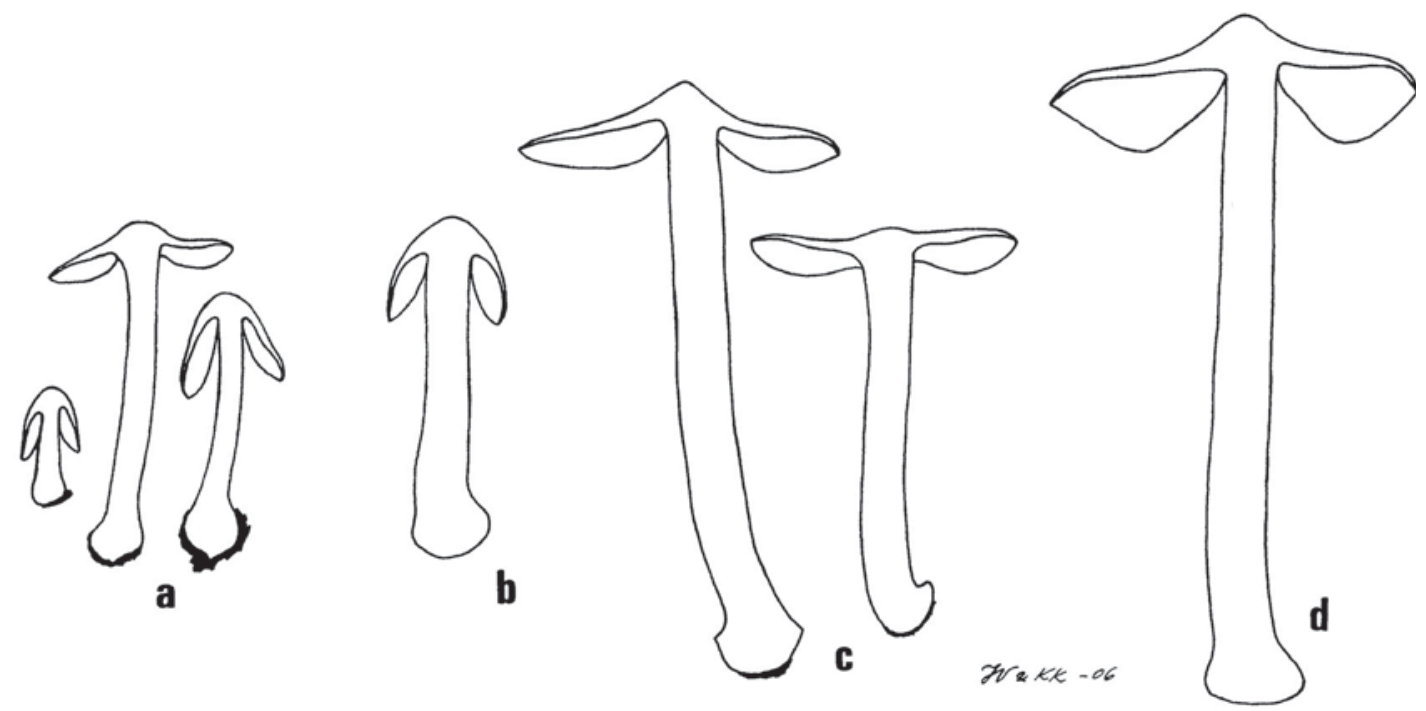

Fig. 3. Fruit bodies of Inocybe saliceticola, $\times 1$ - a) From Vauras $12642 F$, b) Kokkonen 147/03, c) part of holotype, d) Kokkonen 281/03, with untypical broad and ventricose lamellae

to rather frequent. Paracystidia clavate, thinwalled, fairly abundant.

Caulocystidia occurring down to base of stipe, similar to pleuro- and cheilocystidia, but shape more variable, up to $99 \mu \mathrm{m}$ long. Cauloparacystidia clavate, wall thin to slightly thickened, rather abundant, often in clusters.

\section{Ecology, distribution and phenology}

Inocybe saliceticola is a mycorrhizal species of Salix in moist habitats. We have always collected it near willows, usually in alluvial shore thickets or shore forests, but also once in a moist, abandoned sand pit. At least Salix phylicifolia or $S$. myrsinifolia is a host, because no other arboreal plants were recorded at one site. Other usual companions on shores are $S$. pentandra, S. cinerea, Alnus incana and Betula.

Inocybe saliceticola grows on leaf litter or amongst mosses such as Calliergon cordifolium, Sphagnum squarrosum and Mnium. Typical vascular plants at the sites are Lysimachia thyrsiflora, Ranunculus repens, Galium palustre, Potentilla palustris and Calamagrostis canescens. It shares the sites with e.g. Inocybe acuta Boud. (syn. I. acutella Bon) and I. lacera var. helobia Kuyper. Soil is at least moderately rich and varies from turf to mull to fine sand. Soil characteristics varied as follows: $\mathrm{pH} 4.9-5.3, \mathrm{Ca}$
668-1490 mg/l, K 146-226 mg/l, Mg 137-309 $\mathrm{mg} / \mathrm{l}, \mathrm{P} 3.5-7.7 \mathrm{mg} / \mathrm{l}$.

The collections of Inocybe saliceticola date from late July to early October. At present, we know only localities from Finland and one locality from Sweden. In Finland, it has been collected from the eastern, southern and northern parts of the country, ranging from the hemiboreal to the northern boreal zone (Fig. 5). Most of the specimens were collected in the province of Pohjois-Karjala, where the species is not rare in suitable habitats.

Specimens examined: FINLAND. Varsinais-Suomi. Dragsfjärd, Holma, 27.IX.1995 Vauras 10868, GenBank no. FJ755798 (TUR-A)*. Koski T1, Sulkalammi, 2.IX.1991 Heinonen \& Vauras 5995F (TUR-A, GB). Kustavi, Puorenjärvi, 31.VII.1993 Vauras 8015F (TUR). Uusimaa. Espoo, Nuuksio, 31.VIII.1994 Kytövuori 94115 (H). Satakunta. Luvia, Porsmusa, 10.IX.1997 Vauras $12642 F$ (TUR-A). Pohjois-Savo. Kuopio, Kolmisoppi, 2.VIII.1986 Vauras 2144 (TUR-A). Pohjois-Karjala. Ilomantsi, Särkkä, 30.VIII.1996 Jakobsson 1979A (TURA). Nurmes, Metsä-Vastimo, 20.VII.2002 Kokkonen (TUR), 9.VIII.2002 Kokkonen (TUR), 31.VIII.2002 Kokkonen (TUR), 31.VII.2003 Kokkonen \& Vauras 19739F (TUR-A), 8.VIII.2003 Kokkonen 106/03, 1058/03 (TUR), 30.VIII.2003 Kokkonen 292/03, 294/03 (TUR); Pahakala, 26.VIII.2002 Kokkonen (TUR), 31.VII.2003 Kokkonen \& Vauras 19738 F (TUR-A, holotype, MICH, isotype), 4.VIII.2003 Kokkonen 98/03 (TUR, MICH), 18.VIII.2003 Kokkonen 147/03 (TUR), 27.VIII.2003 Kokkonen 258/03, 266/03 (TUR), 14.VIII.2005 Kokkonen \& Vauras 23082F (TUR-A, GB, H, L, OULU, UPS). Valtimo, Mahalanniemi, 18.IX.2001 Kokkonen, 

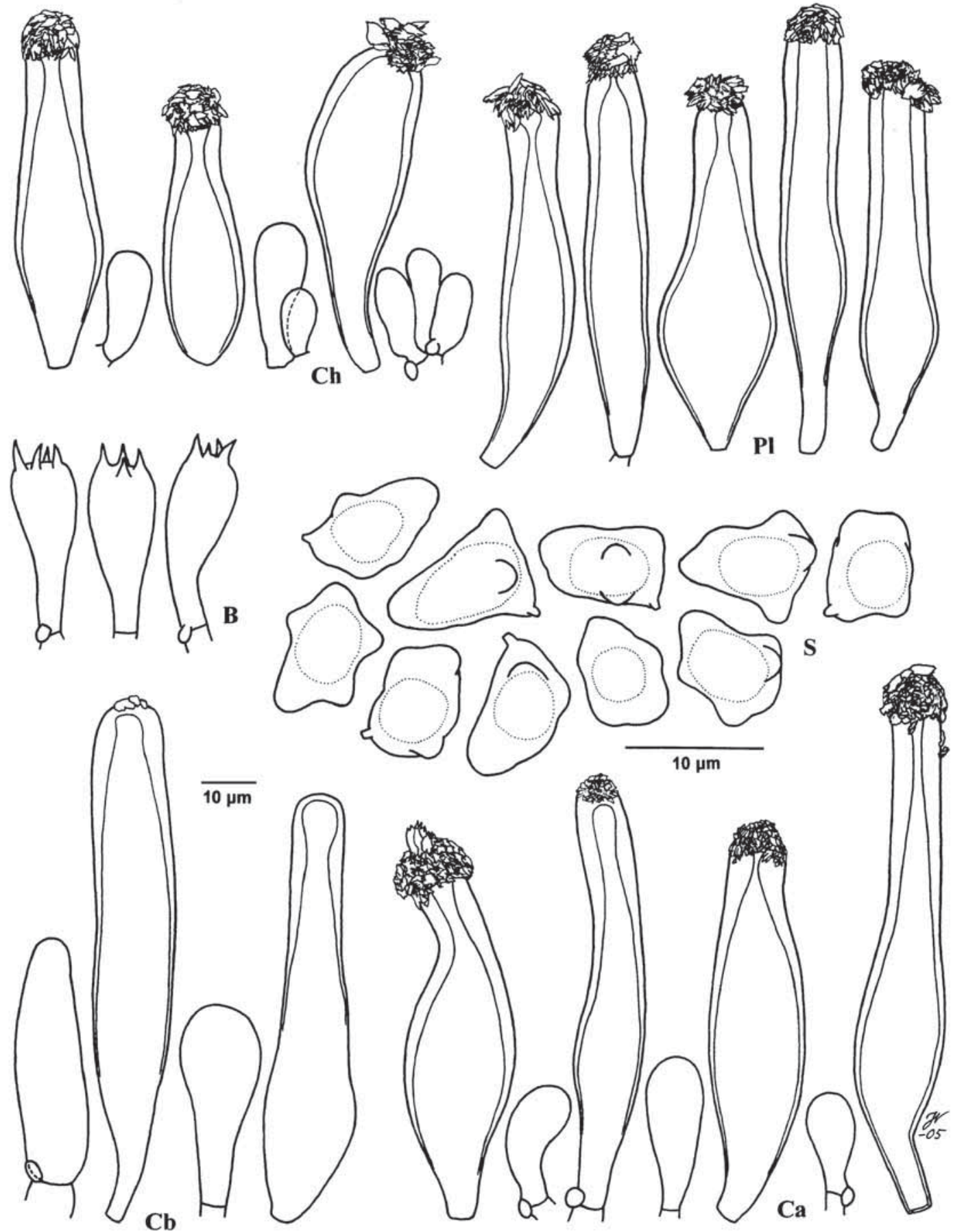

Fig. 4. Microscopical characters of Inocybe saliceticola (holotype). Symbols: $\mathrm{B}=$ basidia, $\mathrm{Ca}=$ caulocystidia and paracystidia at apex of stipe, $\mathrm{Cb}=$ caulocystidia and paracystidia at base of stipe, $\mathrm{Ch}=$ cheilocystidia and paracystidia, $\mathrm{Pl}=$ pleurocystidia, $\mathrm{S}=$ spores. Scales: spores $\times 2000$, others $\times 800$. 


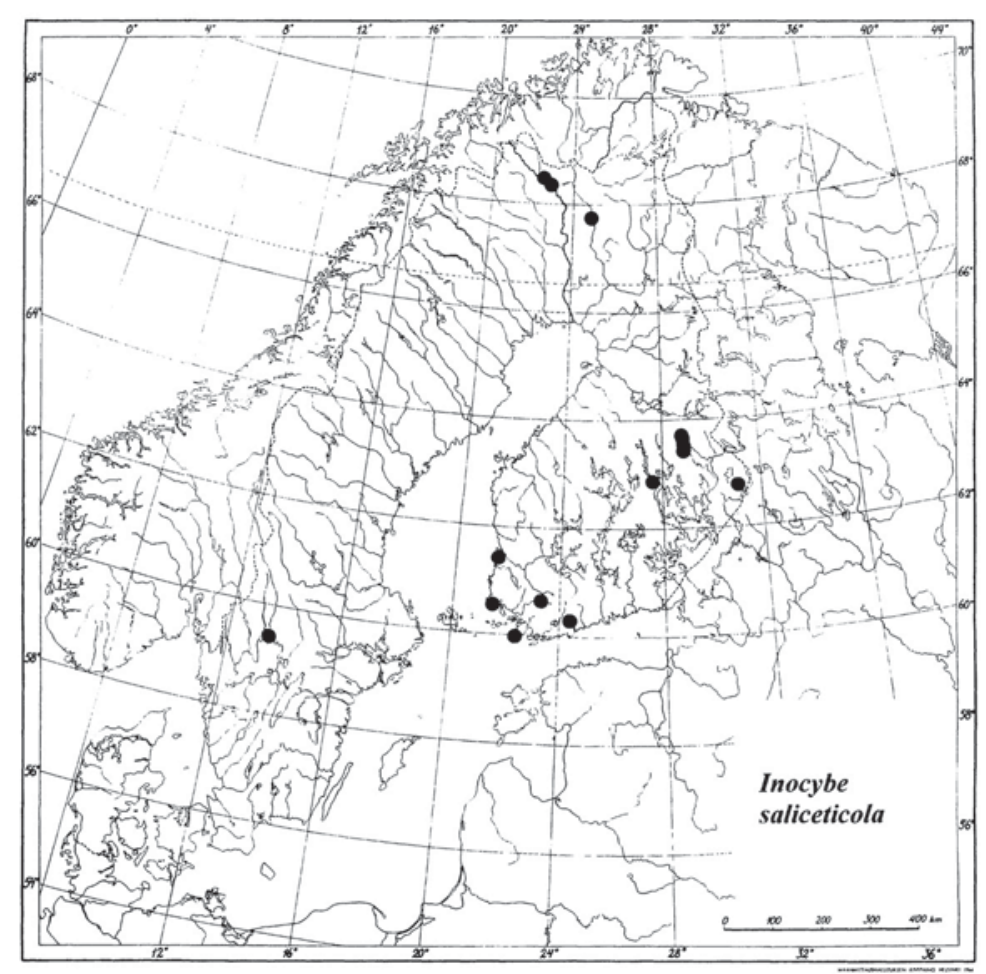

Fig. 5. Distribution of Inocybe saliceticola in NW Europe according to the specimens examined.

GenBank no. FJ755799 (TUR-A)**, 2.IX.2002 Kokkonen (TUR), 21.IX.2002 Kokkonen (TUR), 10.X.2002 Kokkonen (TUR-A)*, 1.VIII.2003 Kokkonen \& Vauras 19754 (TUR-A), 10.VIII.2003 Kokkonen 124/03 (TUR), 29.VIII.2003 Kokkonen 281/03, 1059/03 (TUR); Matkusjoki, 3.IX.2002 Kokkonen (TUR). Kittilän Lappi. Kittilä, Sirkka, 16.VIII.2006 Kokkonen 169/06 (TUR-A). Enontekiön Lappi. Enontekiö, Kaaresuvanto, 20.VIII.2006 Kokkonen 262/06 (TUR-A); Vähäniva, 8.VIII.1986 Vauras 2193, GenBank no. FJ755797 (TUR-A)*.

SWEDEN. Värmland. Grava, Klarälven, 30.IX.1989 Jansson (GB), 23.VIII.1990 Jansson (GB).

\section{The other type studies}

Inocybe straminipes Romagn.

- Fig. 6

Inocybe straminipes Romagn., Beih. Sydowia 8: 362. 1979. - Type: France, Coye-la-Forêt (Oise), 18 July 1952 H. Romagnesi 52.46 (holotype PC).

The type consists of one small fruit body. Spores $(10.3-) 10.5-\underline{11.3}-11.8(-11.9) \times(7.4-)$ 7.7- $\underline{8.3}-9.1(-9.3) \mu \mathrm{m}, \mathrm{Q}=1.2-\underline{1.36}-1.5$. Pleuro-

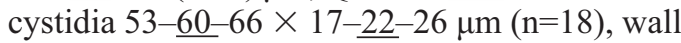
up to $4 \mu \mathrm{m}$ thick, colourless. Basidia 4-spored, 26-36 $\times 10-15 \mu \mathrm{m}(\mathrm{n}=3)$. The stipe was not studied, because it was small and hard.
Inocybe dunensis P.D. Orton - Fig. 6

Inocybe dunensis P.D. Orton, Trans. Br. Mycol. Soc. 43: 277. 1960. - Type: England, Lancashire, Freshfield, 9 July 1956 P.D. Orton 912 (holotype $\mathrm{K})$.

The type consists of only two pieces of pileus. Spores 10.0-10.9-11.5(-12) × 6.5-7.0-7.5 $\mu \mathrm{m}$, $\mathrm{Q}=1.4-1.55-1.7$. Pleurocystidia 52-57-62 $\times$ $20-25-27 \mu \mathrm{m}(\mathrm{n}=9)$, wall up to $4.5 \mu \mathrm{m}$ thick, yellowish. Basidia often 2-spored, 27-29 × 11$14 \mu \mathrm{m}(\mathrm{n}=3)$.

Inocybe obtusiuscula Kühner - Fig. 7

Inocybe obtusiuscula Kühner, Doc. Mycol. 19 (no. 74): 23. 1988. - Type: France, Savoie, Région de Pralognan, Haute vallée de Champagny, Parc de la Vanoise, sous l'entrée du Cirque du Dard, avec Salix herbacea, alt. 2200 m, exp. N., 23 Aug 1960 R. Kühner "K. 60-56" (holotype $\mathrm{G})$.

The type consists of ca. 4 fruit bodies. Spores $(10.2-) 10.7-\underline{12.4}-14.3(-15.0) \times 6.9-\underline{8.3}-9.2(-$ 10.5) $\mu \mathrm{m}, \mathrm{Q}=(1.2-) 1.25-1.49-1.7(-1.85)$, yellow-brown, thick-walled. Pleurocystidia 53-65- 


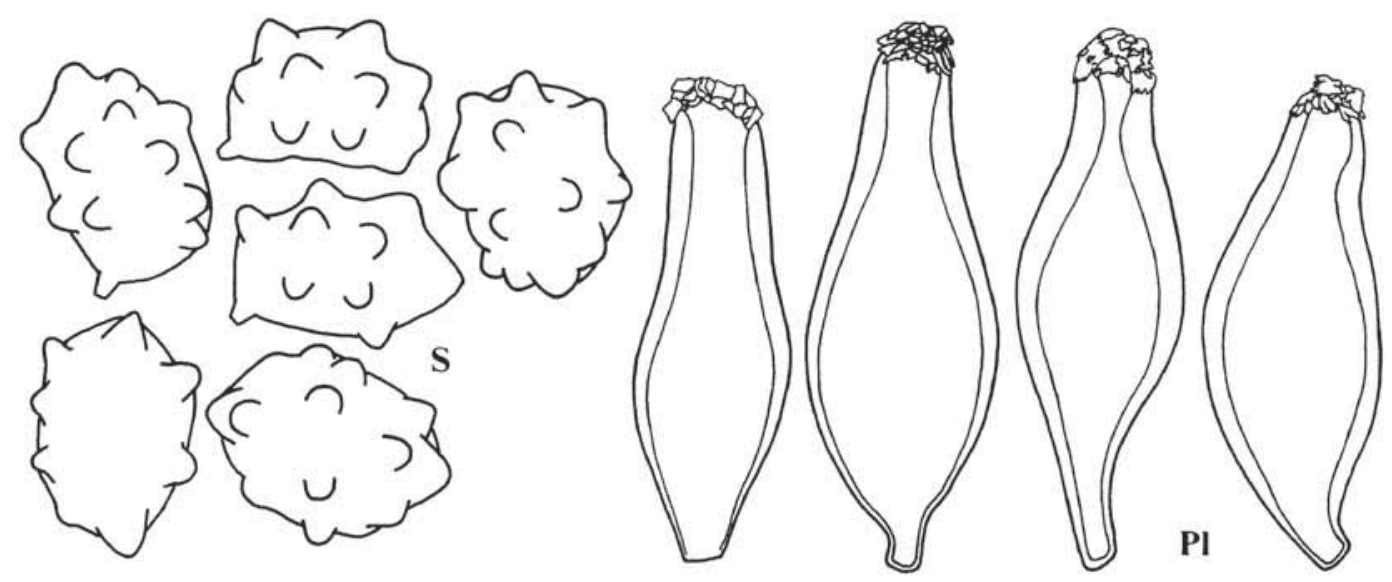

$10 \mu \mathrm{m}$

$\overline{10 \mu \mathrm{m}}$
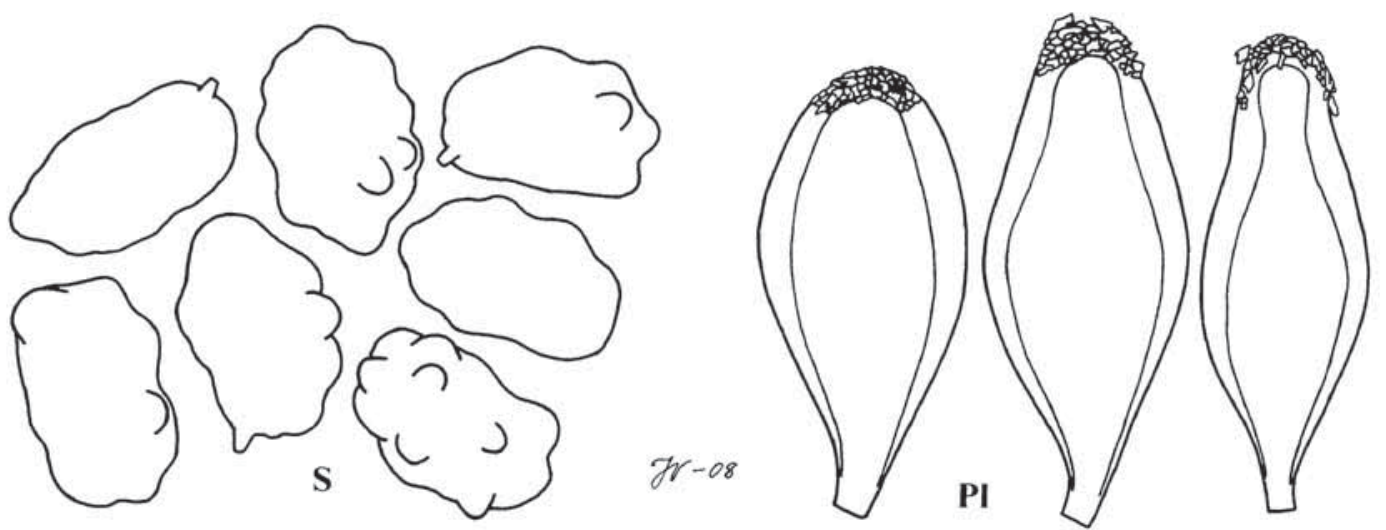

Fig. 6. Spores and pleurocystidia of holotype of Inocybe straminipes (above) and holotype of I. dunensis (below). For scales see Fig. 4.

$75 \times 14-18-26 \mu \mathrm{m}(\mathrm{n}=10)$, wall very slightly yellowish. Cheilocystidia 59-69 × 18-27 $\mu \mathrm{m}$ $(n=3)$, often yellow-brown inside. Caulocystidia from middle part of stipe up to $90 \mu \mathrm{m}$ long, thickwalled, paracystidia often thick-walled. Basidia 4-spored, 31-36 × 11-13 $\mu \mathrm{m}(\mathrm{n}=6)$. GenBank no. FJ755800.

\section{Inocybe alnea Stangl - Fig. 8}

Inocybe alnea Stangl, Z. Mykol. 45: 151. 1979. - Type: Germany, Augsburg, "Gögginger Wäldchen”, 11 Nov 1968 J. Stangl (holotype M).

The type consists of ca. 4 fruit bodies. Spores $(8.8-) 9.3-10.1-11.0(-11.1) \times 7.1-7.8-8.6(-8.9)$ $\mu \mathrm{m}, \mathrm{Q}=(1.15-) 1.2-1.30-1.35(-1.45)$. Pleurocystidia $62-71-83 \times 15-17-20 \mu \mathrm{m}(\mathrm{n}=9)$, wall up to $4 \mu \mathrm{m}$ thick, very pale yellowish. Caulocystidia at stipe apex up to $73 \mu \mathrm{m}$ long, thickwalled. Basidia 33-36× $10 \mu \mathrm{m}(\mathrm{n}=6)$. GenBank no. FJ755801 and FJ755802.

Inocybe ochracea - Fig. 8

Inocybe ochracea Stangl, Z. Mykol. 45: 150. 1979. - Type: Germany, Augsburg, "Gögginger Wäldchen”, 7 June 1968 J. Stangl (holotype M).

The type consists of one fruit body. Spores (8.7-)9.1-10.1-11.2(-11.6)× 6.8-7.4-8.0(-8.3) $\mu \mathrm{m}, \mathrm{Q}=(1.15-) 1.2-1.36-1.55(-1.65)$. Pleurocystidia 52-69-75 $\times 15-17-22 \mu \mathrm{m}(\mathrm{n}=10)$, wall up to $4 \mu \mathrm{m}$ thick, yellowish. Caulocystidia at stipe apex up to $82 \mu \mathrm{m}$, thick-walled. Basidia 27$37 \times 10-12 \mu \mathrm{m}(\mathrm{n}=3)$. GenBank no. FJ755803. 

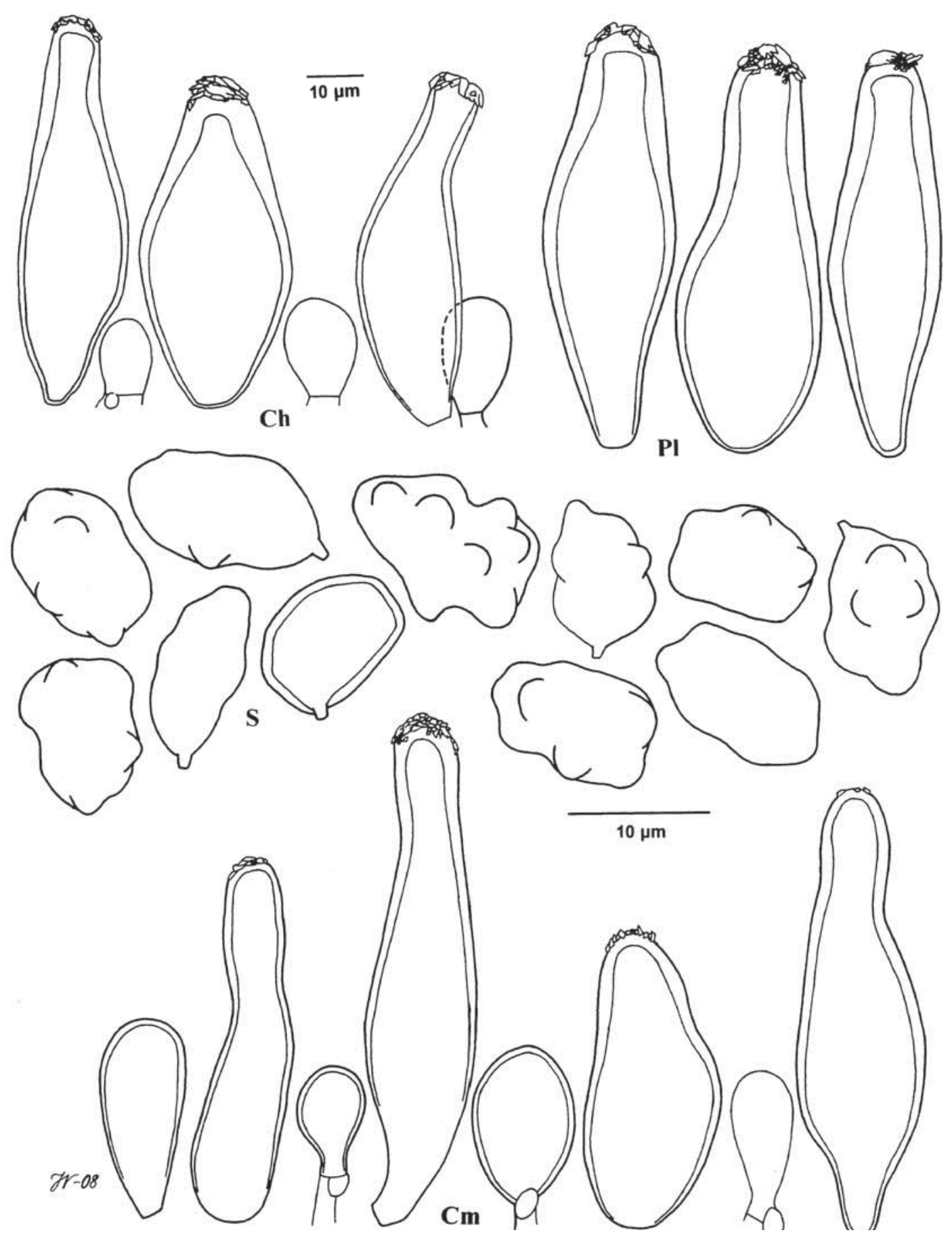

Fig. 7. Microscopical characters of Inocybe obtusiuscula (holotype). For symbols and scales see Fig. 4, but $\mathrm{Cm}=$ caulocystidia and paracystidia at middle part of stipe. 

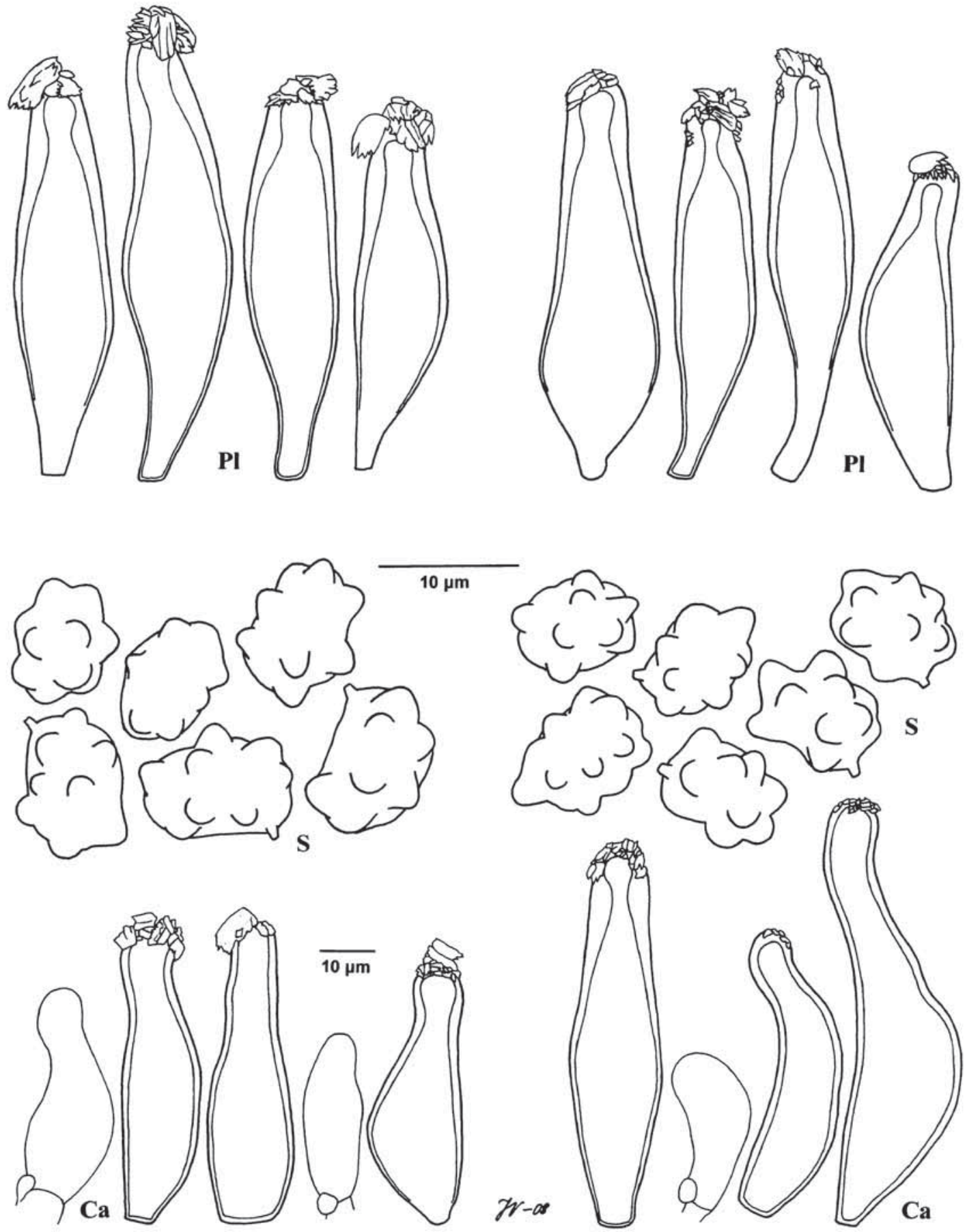

Fig. 8. Comparison of holotypes of Inocybe alnea (left) and I. ochracea (right). For symbols and scales see Fig. 4. 


\section{Differential diagnosis}

Several Inocybe species have been reported to be associated with Salix. Of them I. obtusiuscula Kühner, I. dunensis P.D. Orton, I. salicis Kühner, I. straminipes Romagn., I. salicis-herbaceae Kühner, I. substellata Kühner, I. praetervisa Quél. and I. mixtilis (Britzelm.) Sacc., belonging to the section Marginatae and having ochraceous, fibrillose pileus, resemble $I$. saliceticola macroscopically to some extent. However, they differ by microscopical features. The last six of the above-mentioned species have strongly protruding nodules on spores. Further, I. mixtilis grows mainly with Picea abies, Pinus sylvestris and Betula, and I. praetervisa with at least Betula and Quercus robur in the boreal zone. They also prefer drier habitats. Their only records exclusively with Salix come from the alpine zone (Horak 1987, Bizio 1995, Bizio 1997, Bizio \& Rossi 2002, Ferrari 2006). I. salicis-herbaceae and I. substellata are alpine species (Kühner 1988). Concerning the rest of mentioned species, we have studied the type specimens.

The holotype of I. straminipes proved to be identical with the holotype of I. salicis microscopically (Fig. 6). Kühner (1955) has illustrated I. salicis well. Conversely, the spores of I. straminipes drawn by Romagnesi (1979) in his description deviated from our view. On the ground of our observations, we thus reduce $I$. straminipes to a synonym of $I$. salicis. Having been described earlier, I. salicis has a priority. I salicis seems to differ also ecologically from I. saliceticola. It has been found only once in Finland: from paludified river shore in Kiiminki in Oulun Pohjanmaa (specimen in OULU). The species is rare in the Nordic and Baltic countries, and has been collected mainly on seashore dunes.

The low-nodulated spores of the types of $I$. dunensis (Fig. 6) and I. obtusiuscula (Fig. 7) are distinctly larger and of somewhat different shape compared with I. saliceticola. In addition, cystidia of $I$. dunensis are shorter, and spores of I. obtusiuscula have thicker walls being thus darker. The DNA analysis confirmed that I. obtusiuscula is a clearly separate species from I. saliceticola: there were 46 base pair differences and 6 gaps (length 1-9 bases) within ITS1 sequence. The analysis of ITS2 of I. obtusiuscula failed. It is an alpine species (Kühner 1988). I. dunensis grows on fine sand, mainly at seashores, and has not been found in Finland.

Also Inocybe alnea Stangl and I. ochracea Stangl resemble $I$. saliceticola macroscopically to some extent, but they are possibly not associated with Salix. According to our type studies, they have more protruding nodules on spores (Fig. 8) compared with I. saliceticola. Further, the ITS sequence of $I$. alnea and I. ochracea likewise differed by 60 base pairs and 19 gaps (length 1-11 bases) from $I$. saliceticola indicating separate species (when part of the conservative $5.8 \mathrm{~S}$ of $I$. alnea failed). The microscopical features of I. alnea and I. ochracea proved to be nearly identical, having only slightly different spore sizes, and the DNA analysis supported their conspecificity: the ITS sequences were identical despite one base pair difference and a gap of two bases. Already Zitzmann (2002) regarded them conspecific, and chose the name I. alnea to remain. Stangl (1979) described these species in the same article. According to Stangl (1989), the abundant velipellis of $I$. ochracea and rimose pileus of $I$. alnea were the most distinct differences between these species.

Inocybe hirculus Vauras grows like I. saliceticola in moist habitats, preferring eutrophic fens (Vauras 1994). In one case both species were collected close to each other. Compared with I. saliceticola, I. hirculus differs e.g. by the woolly-fibrillose pileus, the stipe base lacking a bulb, and larger spores. The holotype of I. hirculus (GenBank no. FJ531872) differed by 50 base pairs and 18 gaps (length $1-17$ bases) from the holotype of I. saliceticola, when ten bases were missing from the beginning of I. hirculus sequence.

Inocybe rivularis Jacobsson \& Vauras grows in moist habitats, too. It differs e.g. by larger size, having the stipe pruinose at apex only, and dissimilar microscopical characters (Jacobsson \& Vauras 1990).

Lastly, the prominence of nodules and the shape of spores varies rather much between $I$. $s a$ liceticola collections. Sometimes aberrant spores may have resulted from hard weather conditions. Three collections with atypical spores had an identical ITS area with the holotype despite one gap (1 base) in one collection. One atypical specimen with normal spores has a nearly glabrous stipe. It differed from the holotype by one base pair and one gap (1 base) in ITS. 
Acknowledgements: We are grateful to Tomi Laukka for guidance in DNA analysis. Mika Toivonen is thanked for sequencing two specimens and discussions, Ellen Larsson for dialogue concerning phylogenetic relationships among species of Inocybe, for critical reading of the manuscript and for sending important material from GB, and Seppo Huhtinen for help in practical things. Curators of herbaria G, M and PC are gratefully acknowledged for arranging loans, and Ilkka Kytövuori and Stefan Jakobsson for allowing us to study their collections.

\section{References}

Bizio, E. 1995: Alcune Inocybe più frequenti della zona alpina delle Dolomiti. - Riv. Micol. Suppl. 2: 3-60.

Bizio, E. 1997: Alcune Inocybe più frequenti della zona alpina delle Dolomiti. $2^{\circ}$ contributo. - Riv. Micol. 40: 339-362.

Bizio, E. \& Rossi, C. 2002: Descrizione di quattro Inocybe del saliceto nano. - Pagine Micol. 17 Suppl. N. 1: $25-44$

Cailleux, A. 1981: Code des couleurs des sols. - Boubée.

Ferrari, E. 2006: Inocybe alpine e subalpine. Il genere Inocybe (Fr.) nel nord Italia e paesi limitrofi. - Fungi Non Delineati 34-36: 1-457.

Gardes, M. \& Bruns, T.D. 1993: ITS primers with enhanced specificity for basidiomycetes - application to the identification of mycorrhizae and rusts. - Mol. Ecol. 2: 113-118.

Holmgren, P. K., Holmgren, N. H. \& Barnett, L. C. 1990: Index herbariorum 1. The herbaria of the world, 8th ed. - Regnum Vegetabile 120: 1-693.

Horak, E. 1987: Astrosporina in the alpine zone of the Swiss National Park (SNP) and adjacent regions. In: Arctic and alpine mycology II: Proceedings of the
Second International Symposium of Arctic and Alpine Mycology: 205-234. New York \& London.

Jacobsson, S. 2008: Inocybe (Fr.) Fr. - In: Knudsen, H. \& Vesterholt, J. (eds.): Funga Nordica. Agaricoid, boletoid and cyphelloid genera: 868-906. Copenhagen.

Jacobsson, S. \& Vauras, J. 1990 (“1989”): Inocybe rivularis, a new boreal agaric. - Windahlia 18: 15-24.

Kühner, R. 1955: Compléments a la "Flore analytique". VI) Inocybe goniosporés et Inocybe acystidiés. Espèces nouvelles ou critiques. - Bull. Soc. Mycol. Fr. 51: 169-201.

Kühner, R. 1988: Diagnoses de quelques nouveaux Inocybes récoltés en zone alpine de la Vanoise (Alpes françaises). - Doc. Mycol. 19 (no.74): 1-27.

Küppers, H. 1999: DuMont's Farbenatlas. $7^{\text {th }}$ ed. -165 pp. Köln.

Romagnesi, H. 1979: Quelques espèces rares ou nouvelles de Macromycetes. III. - Inocybe. - Beih. Sydowia 8: 349-365.

Stangl, J. 1979: Die eckigsporigen Rißpilze (4). - Z. Mykol. 45: 145-162.

Stangl, J. 1989: Die Gattung Inocybe in Bayern. - Hoppea, Denkschr. Regensb. Bot. Ges. 46: 5-388.

Vauras, J. 1994: Finnish records on the genus Inocybe. The new species I. hirculus. - Aquilo, Ser. Bot. 33: 155-160.

White, T.J., Bruns, T., Lee, S. \& Taylor, J. 1990: Amplification and direct sequencing of fungal ribosomal RNA genes for phylogenetics. - In: Innis, M.A., Gelfand, D.H., Sninsky, J.J. \& White, T.J. (eds.), PCR Protocols: a Guide to Methods and Applications: 315-322. New York.

Zitzmann, H. 2002: Regensburger Pilzflora 12. Die Gattung Inocybe. - Reg. Mykol. Schr. 10: 135-288. 